\title{
ANTIMICROBIAL EFFECTS OF ESSENTIAL OILS FROM Tanacetum vulgare L. AND Salvia officinalis L., GROWING IN SLOVAKIA
}

\author{
MÁRIA MIKULÁŠOVÁ ${ }^{1}$, ŠTEFÁNIA VAVERKOVÁ \\ ${ }^{1}$ Institute of Cell Biology, Faculty of Natural Sciences, Comenius University, Mlynská \\ dolina, Bratislava, SK-842 15, Slovak Republic (mikulasovam@fns.uniba.sk) \\ ${ }^{2}$ Department of Pharmacognosy and Botany, Faculty of Pharmacy, Comenius \\ University, Odbojárov 10, Bratislava, SK- 83232, Slovak Republic \\ (vaverkova@fpharm.uniba.sk)
}

\begin{abstract}
Possible antimicrobial properties of essential oils isolated from Tanacetum vulgare L., and Salvia officinalis L., harvested from five different locations in Slovakia, were examined using the disc agar diffusion method and by the microdilution method. GC/MS analysis of the essential oil from Tanacetum vulgare $\mathrm{L}$. resulted in the identification of 16 compounds constituting $82.1 \%$ of the total oil. Gram-positive bacteria, mainly Bacillus subtilis, were more susceptible to essential oils from both plants than were gramnegative species. Tested essential oils posses also anti-yeast activity. The shares of the constituents in the essential oils as well as their antimicrobial activity differed in dependence on the locality.
\end{abstract}

Key words: Essential oils, Tanacetum, Salvia, antimicrobial

\section{Introduction}

Essential oils are volatile compounds of plant secondary metabolism, and may act as phytoprotective or insecticide agents. These compounds also have antibacterial and antifungal activity, which is important both for food preservation and control of human and plant diseases of microbial origin. The quality and yield of essential oils is influenced by many factors, such as fertilizer and $\mathrm{pH}$ of soil (ALVAREZCASTELIANOS and PASCUAL-VILLALOBOS, 2003), chemotype or subspecies (GOREN et al., 2001), choice of plant part (KESKITALO et al., 2001), harvesting season (CORNU et al., 2001), the choice and stage of drying conditions (TATEO and RIVA, 1991) and extraction method (SCALIA et al., 1999). The content of some components of essential oils varies according to the geographic location. Thus, 1,8cineole was the most abundant in the oil of sage from the USA (18.0\%), camphor in the oil of Romania (26.5\%), caryophallene in the oil from the USA (10.0\%), alphathujone in the oil from Italy (45.8\%), beta-thujone in the oil from Romania (23.1\%) (BOELENS and BOELENS, 1997). The composition of the essential oils from various chemotypes of Tanacetum vulgare was studied in detail on populations of wild growing species in Finland (KESKITALO et al., 2001), Norway (DRAGLAND et al., 2005), Hungary, Poland, Italy, and others. In our previous work (VAVERKOVÁ et al., 2006) we examined qualitative properties of the essential oil obtained from Tanacetum vulgare $\mathrm{L}$. and we confirmed that the shares of the constituents in the essential oils differ in dependence on the location.

The purpose of this work was to estimated and compared antimicrobial activity of extracts from Tanacetum vulgare and Salvia sp. from some geographic locations in Slovakia. 


\section{Material and methods}

\subsection{Plant material and GC/MS analyses of essential oils}

Tanacetum vulgare L. and Salvia officinalis L. were used as a testing material. Collection of the plant has been carried in the phase of full flowering flower heads. Twenty grams of dry flower heads were subjected to hydrodistilation for 3.5 hours in accordance to the European Pharmacopoea. Isolated oil was diluted in n-hexane and dried over anhydrous sodium sulphate. Oil samples were analyzed using a Hewlett Packard HP 5971. A mass selective detector directly coupled to a gas chromtaograph HP 5890 Series II FID was used. A capillary column DB-WAX/26m x 0.20 mm, 0.2 $\mathrm{mm}$ film thickness (Hewlett Packard, USA) was used. Detailed agro-ecological characteristics of individual locations are archived at the workplace of authors.

\subsection{Microbial strains}

Bacterial strains Escherichia coli CCM 3988, Proteus mirabilis CCM 1941, Staphylococcus aureus CCM 3953, Micrococcus luteus CCM 732, Bacillus subtilis CCM 1718 and the yeasts Saccharomyces cerevisiae, Candida albicans, Candida parapsiloides and Rhodotorula glutinis were obtained from the Czech Collection of Microorganisms, Brno, Czech republic.

\subsection{Antimicrobial activity}

Disc diffusion method - nutrient agar plates were swabbed with the respective broth culture of the organisms (diluted to $0.5 \mathrm{McF}$ arland standard with saline). Filter paper discs $(6 \mathrm{~mm}$ in diameter) were impregnated with $5 \mu \mathrm{l}$ of the extract and placed on the inoculated plates. These plates, after staying at $4^{\circ} \mathrm{C}$ for $2 \mathrm{~h}$, were incubated at $37^{\circ} \mathrm{C}$ for $24 \mathrm{~h}$ for bacteria and at $28^{\circ} \mathrm{C}$ for $48 \mathrm{~h}$ for the yeasts. The diameters of the inhibition zones were measured in millimeters.

Determination of minimum inhibitory concentration - was performed using broth microdilution method. The overnight growing culture of bacteria was filtered and $2 \%$ suspension of bacteria was prepared. $180 \mu \mathrm{l}$ of this suspension and $20 \mu \mathrm{l}$ of double diluted solutions of EO were placed into the wells of 96 well microtitre plates and cultivated for $24 \mathrm{~h}$ on reciprocal shaker at $37^{\circ} \mathrm{C}$. The time course of absorbance $\left(\mathrm{A}_{630}\right)$ was determined at $120 \mathrm{~min}$ intervals in triplicates.

\section{Results and discussion}

\subsection{Chemical composition of the essential oil}

The following compounds were identified using GC/MS analysis in essential oil from Tanacetum vulgare L., which constituted $82.1 \%$ of total oil: $\alpha$-pinene, camphene, sabinene, $\beta$-pinene, myrcene, 1,8-cineole, artemisia ketone, $\beta$-tujone, 
camphor, borneol, umbellulone, D-carvone, chrysantenyl-acetate, bornyl-acetate, thymol, germacrene and carvacrol. Comparison of these results with those mentioned in literature indicates that these compounds are in the most cases the main components of Tanacetum essential oils. The shares of the constituents in the essential oils differed in dependence on the location.

\subsection{Antimicrobial activity}

As seen in Fig. 1, tested oils from Tanacetum vulgare L., and Salvia officinalis L. showed better activity against Gram-positive bacteria than against Gram-negative ones.
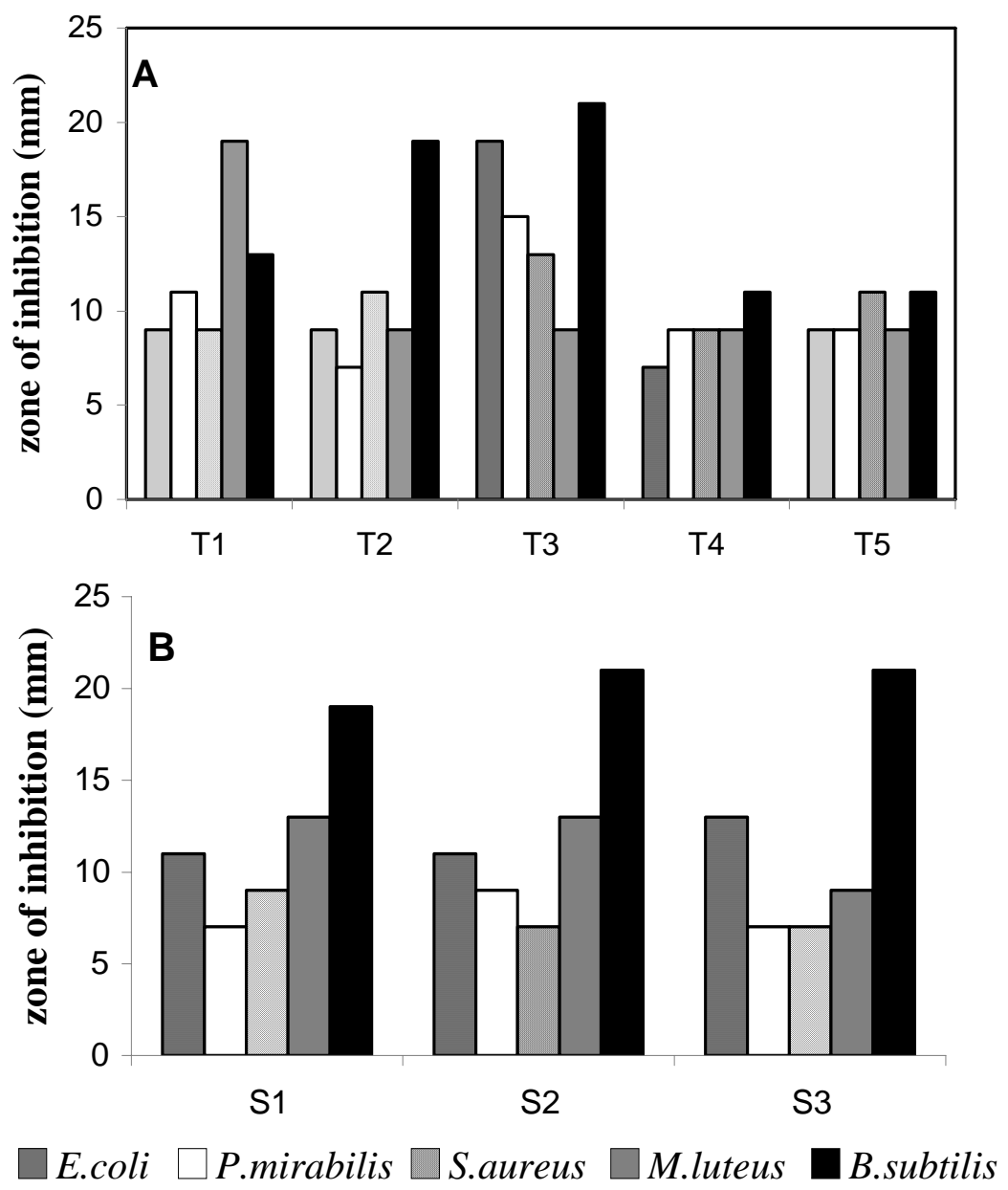

Fig. 1. Antibacterial activity of essential oils from Tanacetum vulgare L. (A) and Salvia officinalis L. (B) from different locations. 
Among the bacteria tested Bacillus subtilis was the most sensitive to all EOs. Other Gram-posititve bacteria show lower susceptibility to the essential oils. From Gramnegative bacteria only Escherichia coli was more susceptible to EO from Salvia officinalis L. Oil from one chemotype of Tanacetum vulgare L. (T3) had very strong effect on both Gram-negative bacteria, but oils from another chemotypes had only very slightly effect. According to KALODERA et al. (1997), oils from Tanacetum are effective on Gram-negative bacteria. However, most studies investigating the antibacterial effects of essential oils confirmed, that they are more active against grampositive than gram-negative bacteria (RANDRIANARIVELO et al., 2009). Our results indicate that this effect differs due to different chemotype of plant, as is state later.

The comparative evaluation of essential oils from two distinct species of plants (Tanacetum vulgare L., and Salvia officinalis L.) showed variations in the level of activity against bacteria. These variations were evident from zones of inhibition as well from MIC values. MIC of essential oils from Tanacetum ranged in all bacteria from $<0.6 \%$ to $>>2.5 \%$. Three essential oils from Salvia had strong effect on Micrococcus luteus and Bacillus subtilis (MIC <0.6\%). In G- bacteria Escherichia coli and Proteus mirabilis MICs of Salvia essential oils ranged from $<0.6 \%$ to $2.5 \%$.

Samples of essential oils T1-T5 originated from the same plant species, were isolated using the same procedures and differ only by the geographic location of plants. As is evident from the comparison of inhibition zones (Fig. 1) and MIC values their antibacterial properties are different. T4 and T5 possess the lowest antibacterial effect and sample T3 posses the best one. MIC of this EO in E. coli, Proteus mirabilis and Bacillus subtilis is $<0.6 \%$, only in Micrococcus luteus is $2.5 \%$.

Essential oils were tested also for their effects on the yeasts. As is evident from the values of inhibition zones in Fig. 2, the more susceptible to EO is Candida albicans. Also on this yeast, the most effective essential oils are T3 from Tanacetum and S1 from Salvia.

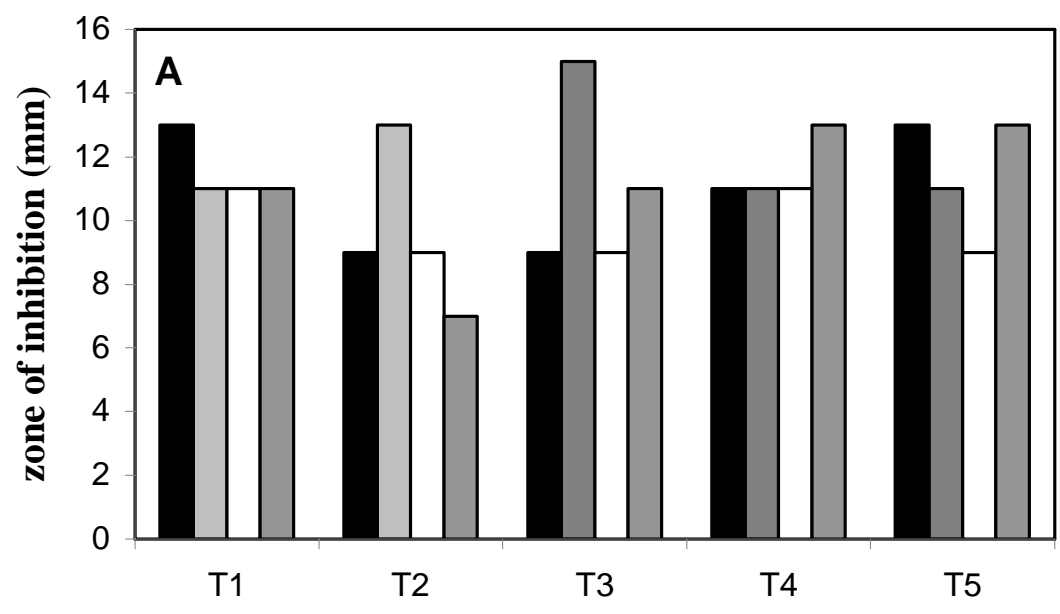




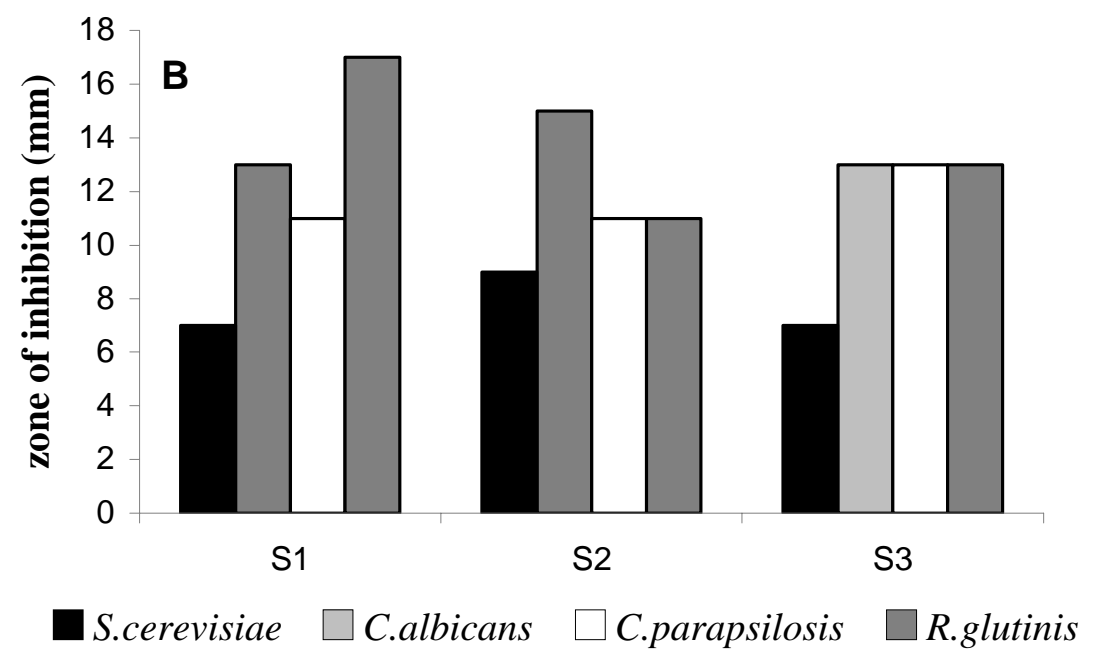

Fig. 2. The effect of essential oils from Tanacetum vulgare L. (A) and Salvia officinalis L. (B) from different locations on the growth of yeasts.

\section{Conclusions}

From this study it can be concluded, that essential oils from Tanacetum vulgare L. and Salvia officinalis L. posse antibacterial and anti-yeast activity. It is known, that the chemical composition of essential oils from plants species can vary according to the geographical origin and harvesting period. Individual components of essential oils exhibit different degrees of antimicrobial activity; therefore variation in composition between batches of essential oils from plants from different locations can be sufficient to cause variability in their antimicrobial effects.

\section{References}

ALVAREZ-CASTELIANOS, P.P., PASCUAL-VILLALOBOS, M.J.: Effect of fertilizer on yield and composition of flowerhead essential oil of Chrysanthemum coronarium (Asteraceae) cultivated in Spain. Ind. Crop Prod., 17, 2003, 77-81.

BOELENS, M. H., BOELENS, H.: Chemical and sensory evaluation of three sage oils. Perfum. Flavor., 22, 1997, 9-39.

CORNU, A., CAMAT, A.P, MARTIN, B., COULON, J.P., LAMAISON, J.L., BERDAGUÉ, J.L.: Solid-phase micro-extraction of volatile components from natural grassland plants. J. Agric. Food Chem., 49, 2001, 203-209.

DRAGLAND, S., ROHLOFF, J., MORDAL, R., IVERSEN, T.H.: Harvest optimization and essential oil production in five tansy (Tanacetum vulgare L.) genotypes under a northern climate. J. Agric. Food Chem., 53, 2005, 4946-53.

GOREN, N., DEMIRCI, B., BASER, K.H.C.: Composition of the essential oils of Tanacetum spp. from Turkey. Flavour Frag. J., 16, 2001, 191-194. 
KALODERA, Z., PEPELJNAK, S., BLAŽEVIČ, N., PETRAK, T.: Chemical composition and antimicrobial activity of Tanacetum parthenium essential oil. Pharmazie, 52, 1997, 885-886.

KESKITALO, M., PEHU, E., SIMON, J.E.: Variation in volatile compounds from Tansy (Tanacetum vulgare L.) related to genetic and morphological differences of genotypes. Biochem. System. Ecol., 29, 2001, 267-285.

RANDRIANARIVELO, R., SARTER, S., ODOUX, E., BRAT, P., LEBRUN, M., ROMESTAND, B., MENUT, C., ANDRIANOELISOA, H.S., RAHERIMANDIMBY, M., DANTHU, P.: Composition and antimicrobial activity of essential oils from Cinnamosma fragrans. Food Chem., 114, 2009, 680-684.

SCALIA, S., GIUFFIREDA, L., PALLADO, P.: Analytical and preparative supercritical fluid extraction of chamonile flowers and its comparison with conventional methods. J. Pharm. Biomed. Anal., 21, 1999, 549-558.

TATEO, F., RIVA, G.: Influence of the drying process on the quality of essential oils in Artemisia absinthum. Mitt.Geb. Leven. Hyg., 82, 1991, 607-614.

VAVERKOVÁ, Š., MIKULÁŠOVÁ, M., HABÁN, M., SLOBODA, P.: A study of qualitative properties of the essential oils of Tanacetum vulgare L. Čes. Slov. Farm., 55, 2006, 181-185. 